\title{
THE NAUPLIAR DEVELOPMENT OF BRYOCAMPTUS ZSCHOKKEI [COPEPODA, HARPACTICOIDA]
}

\author{
par Jouko SARVALA.
}

The naupliar development of Bryocamptus (B.) zschokkei (Schmeil, 1893) (Copepoda, Harpacticoida) is described in detail from larvae reared from the eggs ot females from the High Pyrenees. Six naupliar stages could be separated on the basis of both morphological and biometrical criteria. Certain details of setation and spinulation can be used to separate larvae of $B$. zschokkei from other harpacticoid nauplii.

\section{Le développement nauplien de Bryocamptus zschokkei (Copepoda, Harpacticoida)}

Le développement nauplien de Bryocamptus (B.) zschokkei (Schmeil, 1893) (Copepoda, Harpacticoida) est décrit en détail. L'étude morphologique et biométrique des nauplii et exuvies recueillis dans les élevages a permis de montrer la présence de six stades naupliens chez cette espèce. Certains détails de morphologie distinguent les nauplii de $B$. zschokkei parmi d'autres Harpacticides d'eau douce.

\section{1. - INTRODUCTION}

The larval development of Bryocamptus zschokkei (Schmeil, 1893) was studied by Chappuis (1916), who reported five naupliar stages. Rouch (1968), who published the first description and figures of the nauplii of $B$. zschokkei, also found only five stages. Carter \& Bradford (1972), however, described six naupliar stages in the American B. zschokkei alleganiensis (Coker, 1934). Other recent studies have suggested that the number of naupliar stages in the larval development of all harpacticoids should be six (see Sarvala, in press). A re-examination of the naupliar development even in the European B. zschokkei therefore seemed desirable.

\section{2. - METHODS AND MATERIALS}

Rearing from eggs is usually the only way of being certain that nauplii belong to an identified species. Egg-bearing females of $B$.

1. Lammi Biological Station, University of Helsinki, SF-16900 Lammi, Finland. 
zschokkei were collected in September, 1976, from the stony littoral of a small natural lake (Laquette, $2.079 \mathrm{~m}$ above sea level) near Lake Oredon in the region of Massif du Néouvielle in the central Pyrenees (France). Twelve of them were isolated in small vials, each with $2 \mathrm{ml}$ of filtered water. The vials were kept at room temperature varying from about 15 to $20^{\circ} \mathrm{C}$ in the natural light regime of a room facing north. Sieving residues from natural sediment and small pieces of lettuce pre-soaked in water were given as food. Water was changed and foad added when needed, at about weekly intervals. During one month, 535 moulted exuviae were collected from the vials, mounted permanently in glycerol sealed with Glyceel, and examined and draw with the aid of a drawing tubus at a magnification of about $\times 1550$, using phase-contrast optics (WILD M 20) and oilimmersion. In addition, 144 unflattened living nauplii from the cultures were measured. Nauplii were placed in a drop of water on a slide, covered by a coverslip supported by a couple of short hairs, immobilized by gentle heating, and measured with the aid of an ocular micrometer. Special care was devoted to keeping the particular section being measured exactly horizontal; the coverslip was pushed carefully until the desired position was achieved. It was easy to adjust the position of a specimen for the correct measurement of total length and width, whereas measuring the length of the dorsal shield correctly was found to be difficult.

To check the species identity, the original females were fixed, dissected and mounted in glycerol sealed with Glyceel.

\section{3. - TAXONOMY OF THE MATERIAL STUDIED}

The morphology of the twelve females, the progeny of which constituted my material, agreed for the most part with the descriptions of Bryocamptus (Bryocamptus) zschokkei (Schmeil, 1893) by Gurney (1932), Lang (1948) and Dussart (1967). However, the two short, mediodorsal rows of fine spinules on the genital segment were lacking in nine of the twelve specimens; at least in one such case these spinules appeared in the $F_{1}$ generation. In addition, in most individuals the terminal joint of the endopodites of the second and third pairs of thoracic legs was partially divided into two joints immediately distal to the proximal inner seta. In some specimens there were no indications of such division in leg 2, whereas in leg 3 signs of division were always visible and in some specimens the division was nearly complete. Similar variation within a population was also noted by Carter \& Bradford (1972), in B. zschokkei alleganiensis. Evidently this feature is of little or no taxonomic significance in this species. 


\section{4. - THE NUMBER OF NAUPLIAR STAGES}

The measurements of total length revealed six non-overlapping size groups (Fig. 1, Table 1) which corresponded to morphologically

TABLE 1. - The development of size and form of the nauplii of Bryocamptus zschokkei. The figures denote the mean \pm one standard deviation.

$\mathrm{TL}=$ total length, DS = length of dorsal shield, A2 Enp TS = length of the terminal spine of antennal endopodite, Md Exp2 TS=length of the terminal seta of joint 2 of mandibular exopodite, $n=$ number of specimens measured.

\begin{tabular}{lcccccc}
\hline Stage & N1 & N2 & N3 & N4 & N5 & N6 \\
\hline TL $\mu \mathrm{m}$ & $79 \pm 2$ & $95 \pm 2$ & $111 \pm 3$ & $125 \pm 3$ & $141 \pm 2$ & $160 \pm 3$ \\
Width \% of TL & $82 \pm 3$ & $78 \pm 2$ & $75 \pm 2$ & $73 \pm 2$ & $71 \pm 2$ & $67 \pm 2$ \\
DS \% of TL & $96 \pm 2$ & $95 \pm 3$ & $93 \pm 3$ & $89 \pm 3$ & $84 \pm 3$ & $81 \pm 2$ \\
A2 Enp TS \% of TL & $26 \pm 1$ & $24 \pm 1$ & $23 \pm 1$ & $23 \pm 1$ & $22 \pm 1$ & $21 \pm 1$ \\
Md Exp2 TS \% of TL & $97 \pm 4$ & $88 \pm 3$ & $81 \pm 4$ & $76 \pm 4$ & $74 \pm 3$ & $69 \pm 2$ \\
\hline $\mathrm{n}$ & 22 & 25 & 20 & 21 & 25 & 31 \\
\hline
\end{tabular}

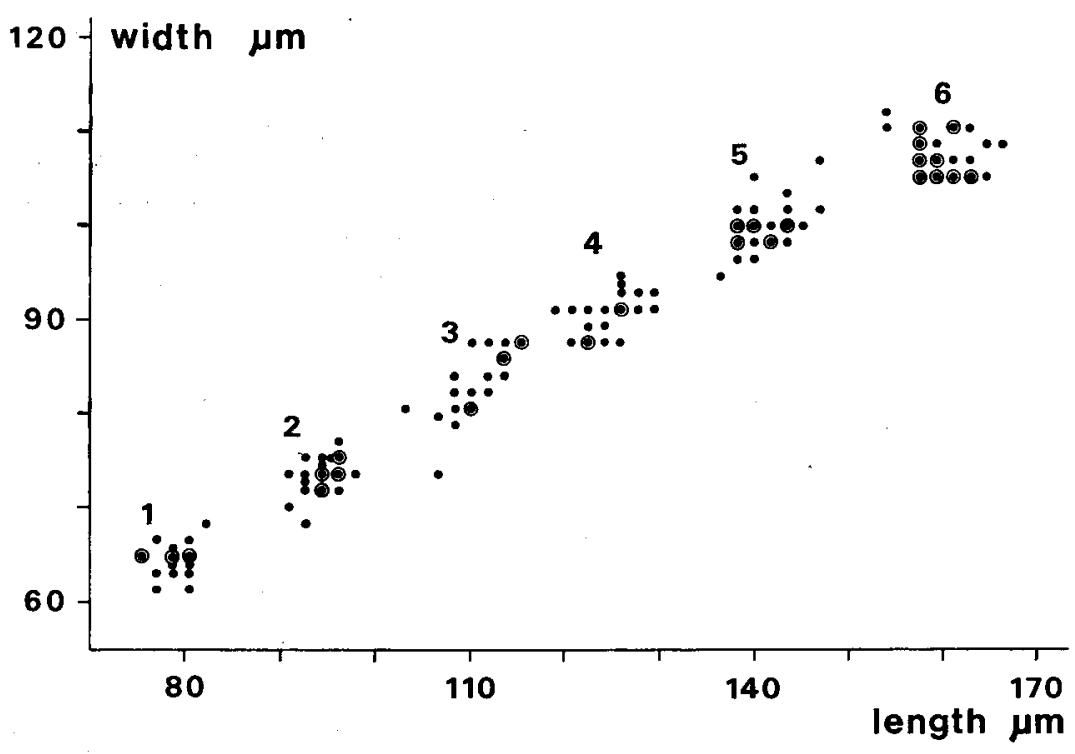

Fig. 1. - Correlation between total length and body width of the naupliar stages of Bryocamptus zschokkei (1-6). Each dot denotes one specimen; circled dots indicate that several (2-5) specimens had the same dimensions. 
distinct naupliar stages. The lengths of the dorsal shield, the maximum body widths and the lengths of setae of the successive stages were slightly overlapping. The ratios of the lengths of the successive developmental stages in copepods have often been assumed to be constant, around 1.25 (see Dussart 1969: 250, Lasker \& al. 1970).

TaBle 2. - The ratios of the mean total lengths of the successive naupliar stages for Bryocamptus zschokkei (from the present material) and for six other harpacticoid species (calculated from Sarvala, in press).

\begin{tabular}{lccccc}
\hline & $\mathrm{N} 2 / \mathrm{N} 1$ & $\mathrm{~N} 3 / \mathrm{N} 2$ & $\mathrm{~N} 4 / \mathrm{N} 3$ & $\mathrm{~N} 5 / \mathrm{N} 4$ & $\mathrm{~N} 6 / \mathrm{N} 5$ \\
\hline Bryocamptus zschokkei & 1.20 & 1.17 & 1.13 & 1.13 & 1.14 \\
Canthocamptus staphylinus & 1.19 & 1.15 & 1.23 & 1.17 & 1.13 \\
C. microstaphylinus & 1.22 & 1.20 & 1.17 & 11.17 & 1.18 \\
Attheyella crassa & 1.17 & 1.18 & 11.17 & 1.10 & 1.13 \\
Moraria brevipes & 1.22 & 1.18 & 1.18 & 1.14 & 1.13 \\
Bryocamptus echinatus & 1.16 & 1.13 & 1.12 & 1.13 & 1.12 \\
Paracamptus schmeili & 1.19 & 1.19 & 1.16 & 1.14 & 1.13 \\
\hline Means for all species & 1.19 & 1.17 & 1.17 & 11.14 & 1.14 \\
\hline
\end{tabular}

In most crustaceans, however, this ratio decreases during development (Mauchline 1976), and a similar trend is evident here (Table 2) both for $B$. zschokkei and in the respective figures calculated from Sarvala (in press) for six other species of freshwater harpacticoids.

\section{5. - MORPHOLOGY OF THE NAUPLIAR STAGES}

The development of the setation and spinulation are summarized in Tables 3 and 4.

\section{Nauplius 1 (Fig. 2).}

Living nauplii fairly transparent; able to swim. Reddish-brown median eyespot present anterodorsally. Dorsoventrally flattened body longer than broad, subcircular, with three pairs of appendages : uniramous antennules and biramous antennae and mandibles. No dorsal ornamentations; anterodorsally on both sides one sensory hair arising from small round depression (see Fig. 8). Labrum pear- 
TABLE 3. - Summary of the development of setation in the nauplii of Bryocamptus zschokkei. The number of setae on each joint is given. $\mathrm{s}=$ spine, $\mathrm{Pl}$ and $\mathbf{P 2}=$ the first and second pairs of thoracic legs, respectively, $\mathrm{p}=$ lobe without setae.

\begin{tabular}{llllllll}
\hline Stage & N1 & N2 & N3 & N4 & N5 & N6
\end{tabular}

Number of specimens examined

$\begin{array}{llllll}86 & 107 & 115 & 96 & 78 & 53\end{array}$

Antennules

joint 1

joint 2

joint 3, ventral

terminal

dorsal

$\begin{array}{rrrrrr}- & - & - & - & - & - \\ 3 & 3 & 3 & 3 & 3 & 3 \\ - & 1 & 2 & 2 & 2 & 2 \\ 2 & 2 & 2 & 2 & 2 & 2 \\ 1 & 1 & 3 & 5 & 6 & 6\end{array}$

\section{Antennae}

coxopodite
basipodite
exopodite joint 1
joint 2
joint 3

endopodite, median

terminal

Mandibles

coxopodite

basipodite

exopodite, joint 1

joint 2

endopodite, terminal

and subterminal
posterolateral

Maxillules

Maxillae

Maxillipedes

P1, endopodite

exopodite

P2, endopodite

exopodite

Furcal setae on each lobe

$\begin{array}{llllll}(1) & 1 & 2 & 2 & 2 & 2 \\ 3 & 3 & 3 & 3 & 3 & 3 \\ 2 & 3 & 3 & 3 & 3 & 3 \\ 1 & 1 & 1 & 1 & 1 & 1 \\ 2 & 2 & 3 & 3 & 3 & 3 \\ 1 & 1 & 1 & 1 & 1 & 1 \\ 1, \mathrm{~s} & 1, \mathrm{~s} & 1, \mathrm{~s} & 1, \mathrm{~s} & 1, \mathrm{~s} & 1, \mathrm{~s}\end{array}$

$\begin{array}{cccccc}1 & 1 & 1 & 1 & 1 & 1 \\ 1 & 1 & 2 & 2 & 2 & 2 \\ 2 & 2 & 2 & 2 & 2 & 2 \\ 2 & 2 & 2 & 2 & 2 & 2 \\ & & & & & \\ 2 \mathrm{~s} & 1,3 \mathrm{~s} & 1,3 \mathrm{~s} & 1,3 \mathrm{~s} & 1,3 \mathrm{~s} & 1,3 \mathrm{~s} \\ 4 & 5 & 5 & 5 & 5 & 5 \\ - & 1 & 1 & 4 & 4 & 4, \mathrm{p} \\ - & - & - & \mathrm{p} & \mathrm{p} & \mathrm{p} \\ - & - & - & - & - & \mathrm{p} \\ - & - & - & - & - & 1 \mathrm{~s} \\ - & - & - & - & - & 2 \mathrm{~s}, 2 \mathrm{p} \\ - & - & - & - & - & \mathrm{p} \\ - & - & - & - & - & 2 \mathrm{~s}, 1 \mathrm{p} \\ 1 & \mathrm{i} & 2,(\mathrm{~s}) & 4 & 5 & 5\end{array}$


TABLE 4. - Summary of the development of spinulation in the nauplii of Bryocamptus zschokkei. The range of observed numbers of spinules in each row is given.

\begin{tabular}{lcccccc}
\hline Stage & N1 & N2 & N3 & N4 & N5 & N6 \\
\hline $\begin{array}{l}\text { Number of specimens examined } \\
\text { Antennules }\end{array}$ & 86 & 107 & 115 & 96 & 78 & 53 \\
joint 2, proximal & & & & & & \\
$\quad$ distal & - & - & - & - & - & - \\
joint 3, ventral & $3-5$ & $3-5$ & $4-7$ & $4-8$ & $4-7$ & $4-7$ \\
$\quad$ dorsal & $2-5$ & $2-4$ & $2-5$ & $3-5$ & $2-4$ & $2-4$ \\
& 14 & $1-3$ & $2-3$ & $2-3$ & $2-3$ & 2
\end{tabular}

Antennae

\begin{tabular}{|c|c|c|c|c|c|}
\hline $\begin{array}{r}\text { coxopodite, anterior } \\
\text { posterior }\end{array}$ & $5-8$ & 46 & $0-5$ & $2-4$ & $3-6$ \\
\hline basipodite, anterior & $2-4$ & 24 & $3-5$ & 3-5 & $3-6$ \\
\hline posterior & $2-5$ & a-2 & $1-3$ & $2-3$ & $2-3$ \\
\hline endopodite, median & 一 & 46 & 48 & $6-9$ & $4-7$ \\
\hline $\begin{array}{l}\text { distal } \\
\text { inner median }\end{array}$ & $3-5$ & $3-6$ & $2-5$ & $3-5$ & 3-5 \\
\hline on terminal seta & $2-4$ & $1-3$ & $2-3$ & $2-3$ & $2-3$ \\
\hline
\end{tabular}

Mandibles

$\begin{array}{ccccccc}\text { basipodite, lateral } & 0-4 & 4-11 & 10-13 & 10-15 & >10 & >10 \\ \text { mesial } & 49 & 6-9 & 6-9 & 5-8 & 5-8 & 5-8 \\ \text { endopodite, ventral } & 46 & - & - & - & - & -\end{array}$

Ventral plate

$\begin{array}{lcccccc}\text { ventrolateral, anterior } & - & - & 6-12 & 7-11 & 10-15 & - \\ \text { median, anterior to margin } & 11-16 & 8-11 & - & - & - & - \\ \text { median, marginal } & 9-13 & - & - & - & - & - \\ \text { lateral to furcal setae } & - & 6-9 & 3-5 & 2-5 & - & -\end{array}$

Labrum, lateral hairs

shaped with fairly broad anterior part; posterior margin fringed with stiff hairs and having median protuberance with bunch of longer fine hairs. 


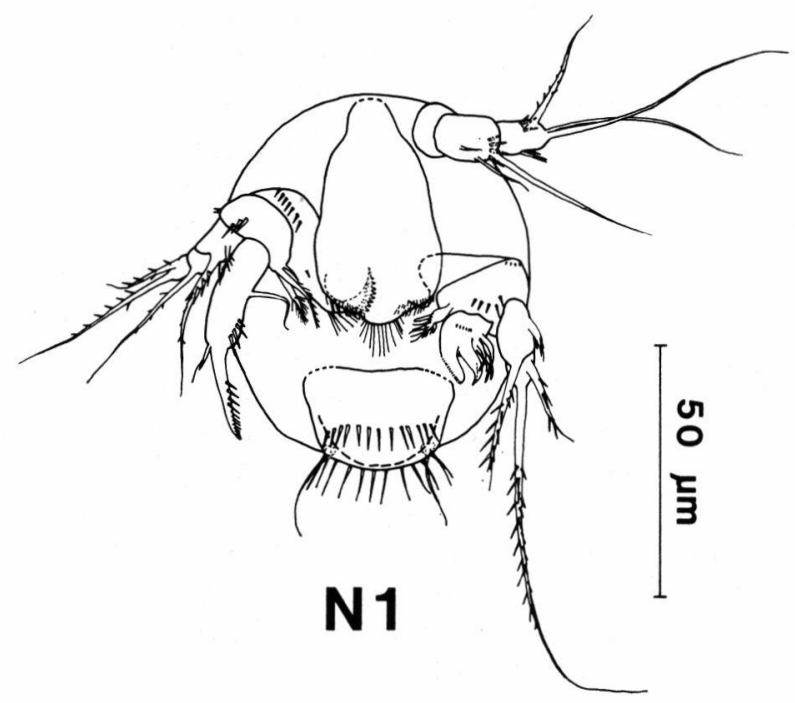

FIg. 2. - The nauplius 1 of Bryocamptus zschokkei in ventral view. For the sake of clarity, only the left antennule and mandible as well as the right antenna are shown, and the structures of the mouth area have been ignored. Setae and spines are distinguished from spinules through their open bases as in Sarvala (in press). Some structures hidden behind other parts are shown with broken lines; some broken lines denote unclear contours (anterior border of labrum and ventral plate). The antennules are shown in such a position that the dorsal setae are directed preaxially.

Mouth area (Fig. 3) dorsal to posterior part of labrum with typical arrangement of very small paragnaths; more posteriorly hairs forming rounded $\mathrm{V}$ pointing towards mouth: hairs forming the point short and stiff, those forming longer and finer.
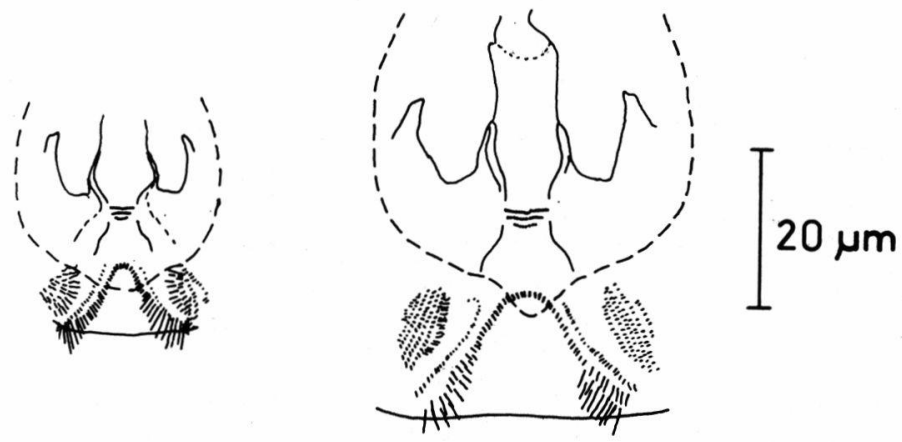

Fig. 3. - The mouth areas of the first (left) and sixth (right) nauplius of Bryocamptus zschokkei. The beginning of the cesophagus is shown anteriorly and the border between mouth area and ventral plate posteriorly; the contours of the posterior part of labrum are indicated with a broken line. 
Ventral plate broader than long, bearing row of slender spinules along its posterior margin, and similar row anterior to margin ; each side of abdomen terminating in relatively short slender seta arising from small dorsal protuberance. Anal operculum rounded, naked.

ANTENNULES. Uniramous, three-jointed. Joint 1 short, naked. Joint 2 half length of antennule; bearing dorsopostaxially distal transverse row of spinules and ventrally three setae : near midlength one short, slightly preaxial and naked seta, distal to midlength one similar but longer seta, and subterminally one heavier, seemingly naked seta longer than antennule. Joint 3 more than half length of joint 2 and narrower; bearing near midlength some long spinules in ventropostaxial transverse or oblique row and somewhat smaller spinules in similar dorsal row ; terminally one slender, naked seta nearly twice length of antennule, and one aesthete about three quarters length of terminal seta and ending in fine hair; subterminally stout dorsal seta, in living specimens often projecting preaxially, and armed with some very small spinules along its median part.

ANTENNAE. Biramous, with one-jointed coxopodite, basipodite and endopodite, and three-jointed exopodite. Coxopodite short, broad, with ventral transverse row of spinules, very small posteroventral seta, and sickle-shaped posteromesial process extending to mouth area dorsal to posterior part of labrum; this process bearing stiff hairs along its posteromedian border, and finer hairs and about 8 equal teeth on its posterodistal margin - these teeth possibly consisting only of tufts of fine hairs or of indentations of thin film. Basipodite also short and broad; bearing some small spinules in anterior distal row and some more conspicuous spinules in more posterior oblique row; and on posteromesial angle bearing one short naked and two longer plumose setae directed towards mouth area. Joint 1 of exopodite longer than broad, nearly half length of whole exopodite, bearing ventropostaxially one median seta shorter than joint and equipped with distal spinules and terminal hair, and one terminal seta, about twice length of whole exopodite and bearing 3-4 very conspicuous spinules on its thick proximal part and small spinules more distad. Joint 2 as long as broad, ventrally with fairly slender terminal seta bearing fine spinules along its median part. Joint 3 slightly longer than joint 2 and narrower, bearing subterminally stout spinulous preaxial seta shorter than exopodite and equipped with terminal hair, and terminally fine-ended seta more than twice length of exopodite and equipped with spinules along its median part. Only joint of endopodite clearly longer than whole exopodite, bearing posteromesial naked seta near midlength, oblique row of distal spinules, small outer terminal seta with terminal spinule and hair, and stout, movable terminal spine as long as joint. This spine bearing on its inner side some coarse median 
spinules in longitudinal row followd more distad by row of finer spinules.

Mandibles. Biramous, with one-jointed coxopodite, basipodite and endopodite, and two-jointed exopodite. Coxopodite subtriangular; its rounded anteromesial corner bearing naked posteromesial seta. Basipodite subrectangular, with proximomesial, typically curved and deformed densely plumose process, and with posterior curved row of spinules, usually also with small anterolateral spinules. Joint 1 of exopodite twice as long as broad; bearing on its proximal half one stout outer seta about half length of joint and equipped with some distal spinules and terminal hair; and stout and spinulous inner terminal seta slightly longer than whole exopodite and ending abruptly in terminal hair. Joint 2 half length of joint 1, triangular; with stiff, spinulous, outer subterminal seta about as long as terminal seta of joint 1 and ending abruptly in terminal hair; and with fine-ended spinulous terminal seta almost as long as whole body. Endopodite about as long as wide; bearing ventral row of very fine spinules; two pincer-like terminal processes as long as joint; and four posterolateral processes; outer terminal process probably feather-like, inner one comb-like with about 15 teeth.

\section{Nauplius 2 (Fig. 4).}

Second nauplius differing fro first in following respects :

Body slightly more elongate; posterior margin lowly emarginate.

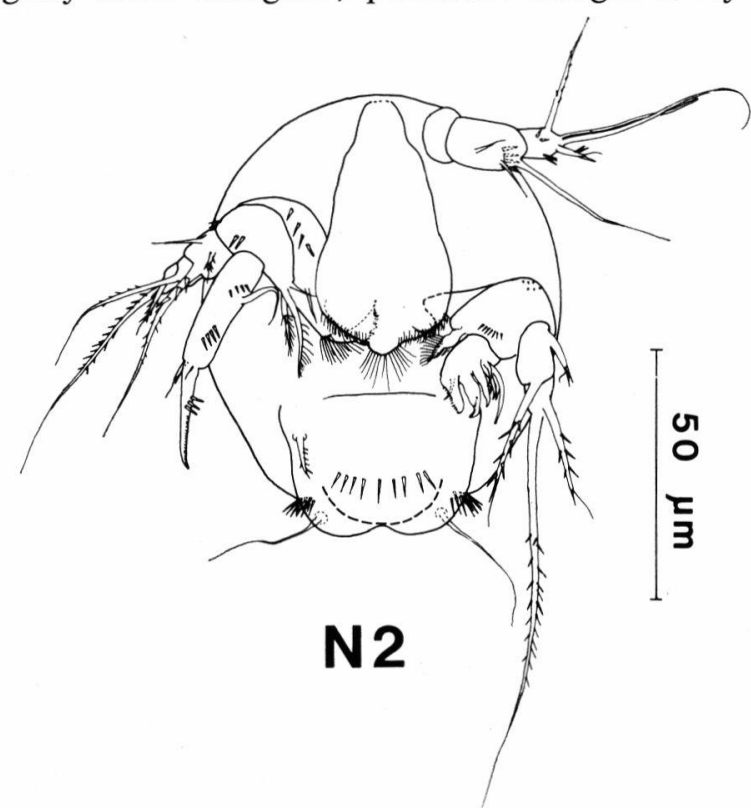

FIG. 4. - The nauplius 2 of Bryocamptus zschokkei in ventral view. Only the right maxillule shown; for further explanation, see Fig. 2. 
Each furcal lobe with transverse row of conspicuous spinules lateral to the only seta ; marginal spinules between furcal setae absent.

ANTENNULES. Joint 3 ventrally with new subterminal seta about as long as joint, having some distal spinules and ending abruptly in terminal hair. Terminal aesthete now without terminal hair.

Antennae. Posteroventral seta on coxopodite lengthened; new low median bulge bearing tuft of stiff posterior hairs present on posteromesial process of coxopodite; distal marginal indentations of this process now uneven. Joint 1 of exopodite with new slender naked seta preaxial to median seta and longer than joint. Endopodite with new row of spinules proximal to midlength. Terminal spine of endopodite with fewer coarse median spinules now in oblique row; distal spinules replaced by more numerous short and very fine hairs, visible only at magnifications of over $\times 1000$; sometimes inner rudimentary seta visible on base of this spine.

MaNDIBLES. Posterior row of spinules on basipodite situated now more mesially and consisting of smaller spinules.

Endopodite without ventral spinules; but with new very delicate terminal seta dorsal to inner terminal process; with new stout subterminal process lateral to terminal processes, resembling these but not as thick; and with new posterolateral process.

MAXILlules. Represented on each side of ventral plate by one stout spinulous anterior seta.

Nauplius 3 (Fig. 5).

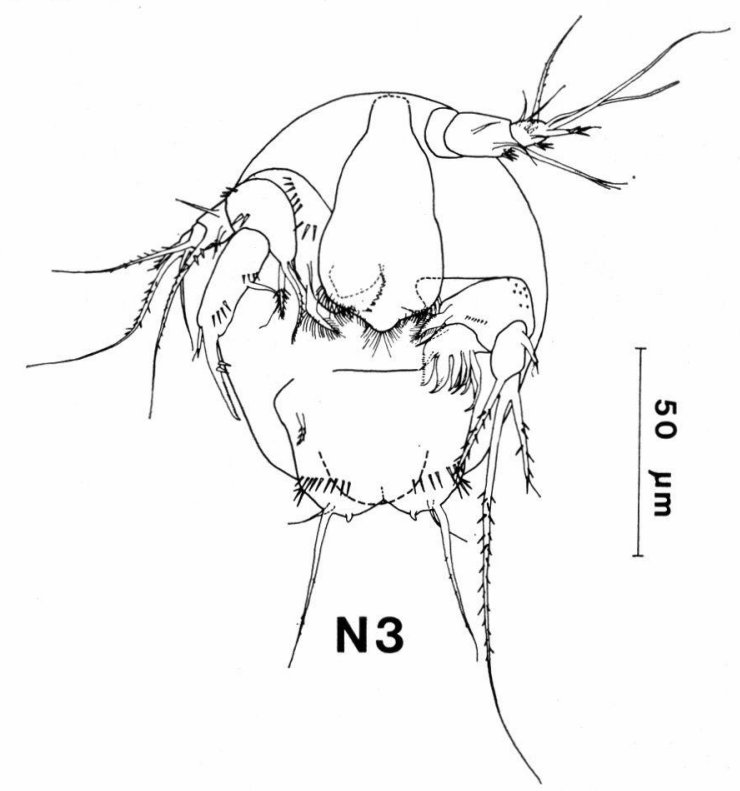

FIG. 5. - The nauplius 3 of Bryocamptus zschokkei in ventral view. For further explanation, see Fig. 2. 
Third nauplius differing from second in following respects :

Each furcal lobe with new, heavy, faintly spinulous marginal seta ventral to earlier seta; and with outward-curved marginal protuberance mesial to setae. Spinules lateral to setae fewer, median spinules anterior to margin absent and replaced by transverse ventrolateral row of spinules on each lobe.

ANTENNULes. Joint 3 ventrally with new small seta near midlength, and dorsally with two new slender setae; one distal to midlength, the other proximal to midlength, both naked.

ANTENNAE. Ventral row of spinules on coxopodite clearly broken into one anterior and one posterior row. Posteromesial process of coxopodite with new plumose posteromedian protuberance instead of bulge bearing tuft of hairs. Joint 3 of exopodite bearing ventropostaxially new slender and naked subterminal seta, slightly shorter than terminal seta of joint 2 .

Mandibles. Basipodite with new slender finely hairy inner process posterodorsally to earlier process.

\section{Nauplius 4 (Fig. 6).}

Fourth nauplius differing from third in following respects :

Body more elongate, abdomen projecting more beyond dorsal shield. Posterior margin of dorsal shield on each side with sensory hair arising from small round depression (see fig. 8); posterolateral corners of dorsal shield drawn to acute processes. Each furcal

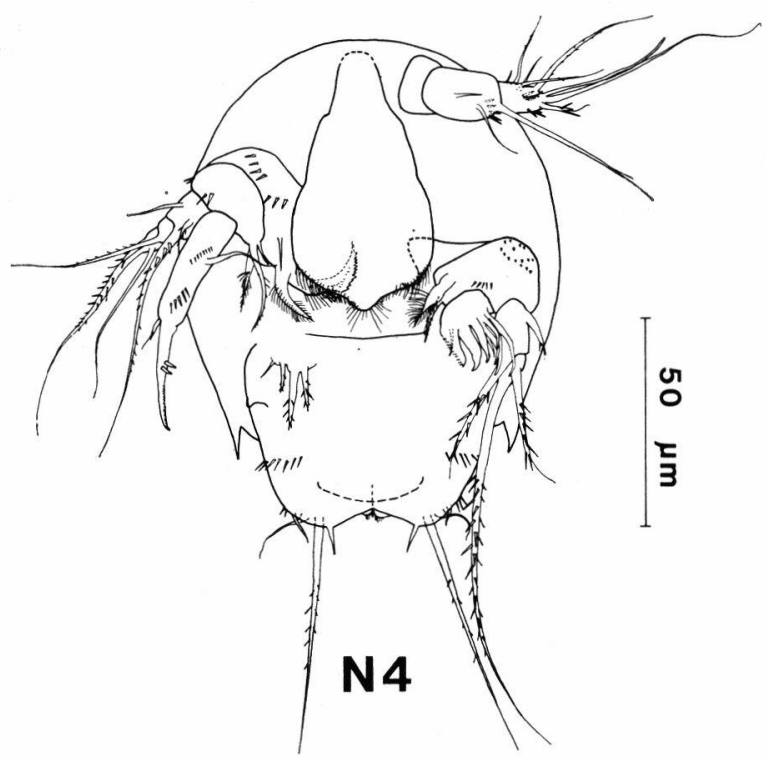

FIG. 6. - The nauplius 4 of Bryocamptus zschokkei in ventral view. Only the lobe of the right maxilla shown; for further explanation, see Fig. 2. 
lobe now with four setae: mesial protuberance of stage 3 replaced by new short naked seta; similar new seta lateral to others; two earlier setae now arising from dorsal side; spinules in group lateral to seta smaller than earlier. Anal region with rows of short hairs or fine spinules; anal operculum shortened.

ANTENNUles. Joint 3 dorsally with two new naked setae: one near midlength, slightly shorter than joint, the other, very small one, proximal to midlength. Earlier mediodorsal setae now longer than joint and equipped with some very fine mediodistal spinules.

MaXILlules. Represented on each side by double lobe: inner bigger part bearing two short stout spinulous setae, the outer and longer of which is about one third length of ventral plate; smaller outer part bearing one inner seta similar to abov-mentioned setae but shorter, and one outer very small naked seta.

Maxillae. Present on each side as transverse lateral fold posterior to maxillules.

Nauplius 5 (Fig. 7).

Fifth nauplius differing from fourth in following respects :

Body more elongate; hind body protruding more beyond dorsal

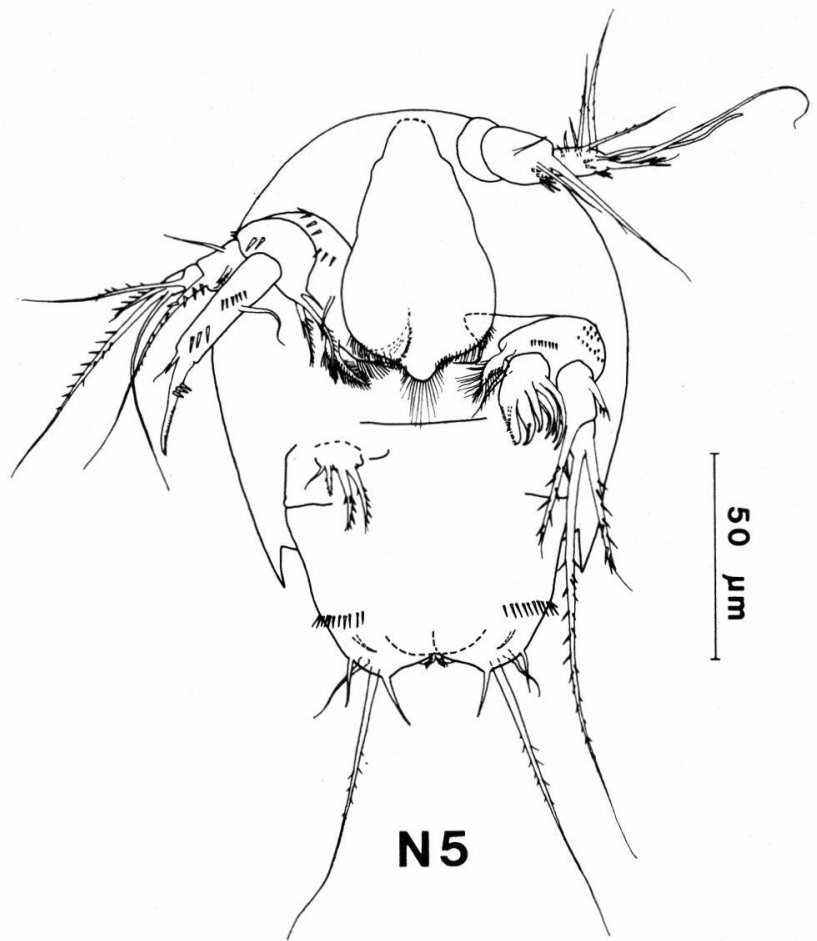

Fig. 7. - The nauplius 5 of Bryocamptus zschokkei in ventral view. For further explanation, see Fig. 2. 
shield. New small dorsal seta present on each furcal lobe anterior to other setae ; the most posterior group of spinules lateral to furcal setae absent.

ANTENNULES. Joint 3 dorsally with new small naked proximal seta.

Maxillules. Earlier double lobe with small new protuberance mesial to setae; new inner lobe without setae usually visible.

Nauplius 6 (Fig. 8).

Sixth nauplius differing from fifth in following respects:

Body more elongate; hind body protruding more beyond dorsal shield ; ventral plate now about as long as broad. Innermost furcal seta now twice as long as fourth seta and about one third length of next inner seta. Ventrolateral spinules on furcal lobes absent. Pair of sensory hairs arising from small round depressions present dorsally anterior to anal operculum.

Maxillules. Also innermost lobe with small mesial bulge.

Maxillae. Posterior margin of fold dentate.

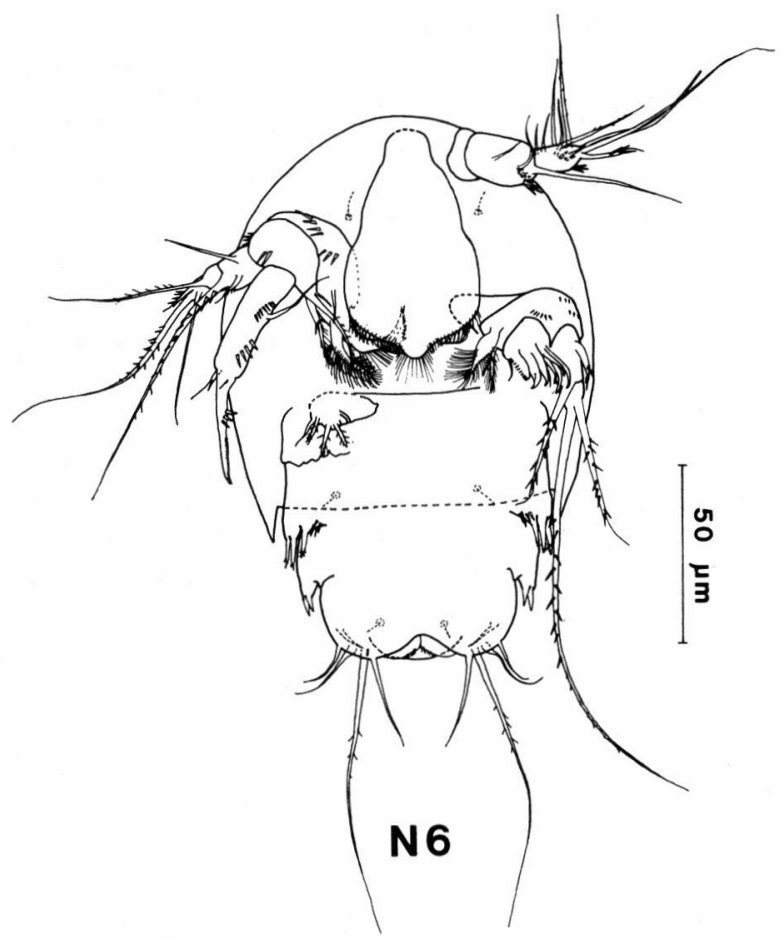

Fig. 8. - The nauplius 6 of Bryocamptus zschokkei in ventral view. Only the right maxillipede shown. The dorsal sensory hairs are also drawn (with broken line). For further explanation, see Fig. 2. 
MAXILlipedES. Represented on each side by small naked lobe mesial to maxillae.

Thoracic Legs. Two pairs of thoracic legs present as lobed buds on both sides of ventral plate. Endopodites of first pair with one lobe with basal spinules and terminal spine, exopodites with two lobes bearing terminal spine and with two naked lobes; endopodites of second pair with one small nake lobe, exopodites with two lobes bearing terminal spine and with one naked lobe.

\section{6.- DISCUSSION}

The present study showed that the European B. zschokkei has six naupliar stages in its development. The general characteristics of the first and sixth nauplius agree with those of other freshwater harpacticoids. The diagnostic features for stages $2-5$, common to the six species studied by Sarvala (in press) - the number of furcal setae and the number of dorsal setae on the terminal joint of antennule - are also applicable to B. zschokkei.

It seems clear that when describing only five stages Rouch (1968) confused stages 4 and 5 , as he now suspects (Rouch, personal communication). The lengths of stages 1, 2, 3, 4, and 5 in Rouch (1968) roughly correspond to those of stages $1,2,3,5$ and 6 in the present work; also, judging from the furcal region, the stage 4 figured by Rouch (p. 122) corresponds to the stage 5 of the present work. Except for the first nauplius the lengths given by Rouch for each stage tend to be slightly smaller than those observed in the present study. This difference migh be real and reflect differing quality and quantity of food in the cultures. In my cultures, nauplii originating from the same female were on average bigger when reared on lettuce than when reared on natural sieving residue; however, a slightly skew position of specimens during measurement can easily lead to smaller values for length. Carter \& Bradford (1972) do not give the size of different stages, so that comparisons with the American form are not possible. In any case, since size is affected by environmental conditions, it can be used for the characterization of the developmental stages only with great reservations.

The description of the development of setation and spinulation by Rouch (1968) was so incomplete that a detailed comparison with the present work is not possible. The overall agreement between the present description and that by Carter \& Bradford (1972) is good, but some differences exist. Carter \& Bradford do not describe the mouth area - only the most posterior hairs are shown in some figures - and they give information on the armature of the terminal spine of the antennal endopodite only in figures, which are variable 
and clearly not accurate in respect to this feature. They have also probably overlooked two small setae on the terminal joint of the antennule : the ventral seta appearing in my material at stage 3 , and one of the dorsal setae appearing at stage 4 ; instead they mention an additional group of spinules appearing at stage 2, but such a group is not visible in their figures of the later stages. Further, Carter \& Bradford have shown the second hairy process of the mandibular basipodite only in figures of stages $4-6$; in my material it was present during stages 3-6. The outermost seta on the maxillules is not mentioned in their text, but it is shown in figures for stages 4 and 6 ; in my material it was present during stages 4-6. Liklewise they show the lobe of the maxilla at stage 4 and the innermost lobe of maxillule at stage 5 only in their figures. Their text concerning the maxillae and maxillipedes at stage 6 is obscure, but the figure is identical with my material, except in showing an additional lateral lobe posterior to the maxillae. According to Carter \& Bradford the posterior border of the anal operculum bears a row of fine spinules at the stage $4-6$; in my material the fine spinules were ventral to the operculum, the margin of which was naked. The order of the appearence of the furcal setae at stages 3 and 4 given by Carter \& Bradford seems to be erroneous, and in their figures setae arising from the dorsal side have been drawn as arising ventrally. In my material the new seta at stage 3 was marginal and heavier and longer than the earlier seta which arises dorsally. Likewise, at stage 4 , the innermost and the outermost setae were new, not the two outermost as claimed by Carter \& Bradford. Finally, the small posterior groups of spinules lateral to the furcal setae are still shown at stage 5 in the figure of Carter \& Bradford; in my material they were present only at stages $2-4$. In my opinion, most of the discrepancies described above can be attributed to the failure by Carter \& Bradford to observe all details, but there remain two minor differences which might be real : the presence of the posterolateral spinules on the abdomen in nauplius 5 and of an additional lateral lobe posterior to the maxillae in nauplius 6 of $B$. zschokkei alleganiensis.

Most earlier descriptions of the naupliar development in other harpacticoids are so incomplete with respect to details of setation and spinulation that comparisons with the present study are difficult. The nauplii of $B$. zschokkei differ from those of B. (Limocamptus) echinatus (Mrázek, 1893) and of five species from other genera studied by Sarvala (in press) at least on the basis of following features :

- lack of proximal spinules on second joint of antennule,

- presence of naked median setae on the same joint,

- arrangement of paragnaths and hairs in the mouth area, 
- time of appearance and type of the second inner hairy process on mandibular basipodite.

The armature of the terminal spine of the antennal endopodite of $B$. zschokkei nauplii is not unique, since at stage 1 it resembles that of $B$. echinatus nauplii, and at stages $2-6$ it is similar to that of Attheyella crassa (Sars, 1863) nauplii.

Besides the features listed above, the nauplii of $B$. zschokkei and $B$. echinatus differ from each other in numerous additional characters. In fact, the differences between these two species are quite comparable to, or even greater than, those between some genera. The examination of naupliar development thus shows clearly that $B$. zschokkei and $B$. echinatus are not very closely related. From a taxonomic point of view, it would be very interesting to know the details of naupliar development in other Bryocamptus species, particularly in the species belonging to the subgenus Arcticocamptus. Among the species placed into the subgenus Bryocamptus, the naupliar development of B. pyrenaicus (Chappuis, 1923), as described by Rouch (1968), seems to be almost identical with that of $B$. zschokkei and judging from the descriptions of Borutskij (1925), the nauplii of B. pygmaeus (Sars, 1863) and B. vejdovskyi (Mrázek, 1893) also resemble those of $B$. zschokkei, although the development of maxillules seems to be different.

Acknowledgements. I am greatly indebted to Prof. E. Angelier and Mrs. Jeanne Rey from the Laboratory of Hydrobiology, Paul Sabatier University of Toulouse, for providing me with working facilities and accommodation at the Vielle-Aure laboratory of the Biological Station of Lake Oredon, as well as for all their help during my visit to Toulouse and the Pyrenees. My thanks are also due to Dr. J. Capblancq and Mr. P. Lavandier for their kind assistance in the collection of field material, and to Dr. R. Jones for improving the English of my manuscript. This study was made possible by grants from the French Government, from the Finnish Ministry of Education and from the University of Helsinki.

\section{REFERENCES}

BORUTSKIJ (E. V.). 1925. - Lichinki presnovodnykh Harpacticoida (Copepoda). (Die Larven der Süsswasser-Harpacticoida (Copepoda).) Trudy Kosinskoj Biol. Stantsii, $3:$ 49-63.

CARTER (M. E.) \& BRADFORD (J.M.). 1972. - Postembryonic development of three species of freshwater harpacticoid Copepoda. Smithsonian Contr. Zool., $119: 1-26$.

ChappuIs (P.A.). 1916. - Die Metamorphose einiger Harpacticiden-genera. Zool. Anz., $48: 20-31$.

DUSSART (B.). 1967. - Les Copépodes des eaux continentales d'Europe occidentale. Tome I : Calanoides et Harpacticoides. Boubée, Paris : 1500. 
DUSSART (B.). 1969. - Les Copépodes des eaux continentales d'Europe occidentale. Tome II : Cyclopoides et Biologie. Boubée, Paris : 1-292.

GuRNeY (R.). 1932. - British fresh-water Copepoda. II. Ray Soc., London : 1-336. LANG (K.). 1948. - Monographie der Harpacticiden. Lund : 1-1682.

LASKeR (R.), Wells (J. B. J.) \& Mc INTYRe (A. D.). 1970. - Growth, reproduction, respiration and carbon utilization of the sand-dwelling harpacticoid copepod, Asellopsis intermedia. J. mar. biol. Ass. U. K., 50: 147-160.

Mauchline (J.). 1976. - The Hiatt growth diagram for Crustacea. Mar. Biol., $35: 79-84$.

Rouch (R.). 1968. - Contribution à la connaissance des Harpacticides hypogés (Crustacés - Copépodes). Ann. Spéléol., $23:$ 5-167.

SARVALA (J.). in press. - The naupliar development of six species of freshwater harpacticoid Copepoda. Ann. Zool. Fennici, 14. 